\title{
Participation in the SUCCESS-A Trial Improves Intensity and Quality of Care for Patients with Primary Breast Cancer
}

\section{Teilnahme an der SUCCESS-A-Studie verbessert Intensität und Qualität der medizinischen Betreuung bei Patientinnen mit primärem Mammakarzinom}

Authors

Affiliations
U. Andergassen ${ }^{1}$, N. S. Kasprowicz ${ }^{2}$, P. Hepp ${ }^{2}$, C. Schindlbeck ${ }^{3}$, N. Harbeck ${ }^{1,4}$, M. Kiechle ${ }^{5}$, H. Sommer ${ }^{1}$, M. W. Beckmann ${ }^{6}$, K. Friese ${ }^{1}$, W. Janni ${ }^{7}$, B. Rack ${ }^{1}$, C. Scholz ${ }^{7}$, for the SUCCESS study group

The affiliations are listed at the end of the article
Key words

- gynecology

- breast cancer

- biomarker

Schlüsselwörter

- Frauenheilkunde

- Mammakarzinom

- Biomarker $\begin{array}{ll}\text { received } & 17.4 .2012 \\ \text { revised } & 13.12 .2012 \\ \text { accepted } & 13.12 .2012\end{array}$

Bibliography

DoI http://dx.doi.org/

10.1055/s-0032-1328147

Geburtsh Frauenheilk 2013; 73 :

63-69 (c) Georg Thieme

Verlag KG Stuttgart · New York ·

ISSN 0016-5751

Correspondence

Dr. Christoph Scholz,

PD Dr. med.

Klinikum der Universität Ulm

Frauenklinik

Prittwitzstraße 43

89075 Ulm

christoph.scholz@

uniklinik-ulm.de

\section{Abstract}

$\nabla$

The SUCCESS-A trial is a prospective, multicenter phase III clinical trial for high-risk primary breast cancer. It compares disease-free survival after randomization in patients treated with fluorouracil, epirubicin and cyclophosphamide followed by 3 cycles of docetaxel (FEC-D) with that of patients treated with 3 cycles of FEC followed by 3 cycles of gemcitabine and docetaxel (FEC-DG). After a second randomization patients were treated with zoledronate for 2 or 5 years. A total of 251 centers took part in the trial and 3754 patients were recruited over a period of 18 months which ended in March 2007. In a questionnaire-based survey we investigated the impact of enrollment in the trial on patient care, the choice of chemotherapy protocol and access to current oncologic information as well as overall satisfaction in the respective centers. Analysis of the 78 questionnaires returned showed that $40 \%$ of the centers had never previously enrolled patients with these indications in clinical studies. Prior to participating in the study, $4 \%$ of the centers prescribed CMF or other protocols in patients with high-primary breast cancer risk, $46 \%$ administered anthracycline-based chemotherapy and 50\% gave taxanebased chemotherapy. Around half of the participating centers noted that intensity of care and overall quality of care became even better and that access to breast cancer-specific information improved through participation in the trial. After their experience with the SUCCESS-A trial, all of the centers stated that they were prepared to enroll patients in clinical phase III trials again in the future. These data indicate that both patients and physicians benefit from clinical trials, as enrollment improves treatment strategies and individual patient care, irrespective of study endpoints.

\section{Zusammenfassung \\ $\nabla$}

Die SUCCESS-A-Studie ist eine prospektive multizentrische Phase-III-Studie beim primären Mammakarzinom. Verglichen wird die rezidivfreien Überlebenszeit nach Randomisierung bei Patientinnen nach 5-Fluorouracil-Epirubicin-Cyclophosphamid (FEC), gefolgt von 3 Zyklen Docetaxel (D) vs. 3 Zyklen FEC, gefolgt von 3 Zyklen Gemcitabin-Docetaxel (DG). Nach erneuter Randomisation erfolgt ein Vergleich einer 2-jährigen vs. 5-jährigen Zoledronat-Therapie. 251 Zentren rekrutierten 3754 Patientinnen in einem Zeitraum von 18 Monaten. Die Auswirkungen der Studienteilnahme auf die Behandlungs- und Versorgungssituation sollten durch einen an die Studienzentren versandten Fragebogen erfasst werden. Nach Auswertung der 78 zurückgesandten Fragebögen zeigte sich, dass $40 \%$ der Zentren ihre Patientinnen zuvor nicht in klinische Studien eingebracht hatten. $4 \%$ verabreichten in einer HighRisk-Situation vor Studienteilnahme CMF- oder ein anderes nicht näher gekennzeichnetes Protokoll. $46 \%$ indizierten eine anthrazyklinbasierte und $50 \%$ eine taxanbasierte Chemotherapie. Die Hälfte der Zentren bemerkten eine größere Betreuungsintensität und eine Verbesserung der Gesamtqualität der medizinischen Betreuung unabhängig von der rein studienbedingten $\mathrm{Zu}$ wendung - sowie einen großen Informationszugewinn durch die Integration in das Studiennetzwerk. Alle Zentren würden nach den Erfahrungen im Rahmen der SUCCESS-A-Studie wieder an einer klinischen Phase-III-Studie teilnehmen. Diese Daten geben einen Hinweis darauf, dass Patientinnen und Ärzte von der Teilnahme an einer Studienteilnahme profitieren, da unabhängig von der erhofften studienspezifischen Therapieverbesserung eine bessere Behandlungsqualität erreicht werden kann. 


\section{Introduction}

$\nabla$

Only a small number of patients with breast cancer receive treatment in clinical trials in Germany. At the same time, clinical studies of breast cancer patients have led to considerable successes in recent years $[17,18]$. The road from routinely performed mastectomy procedures with axillary lymphadenectomy to the current standard of surgical restraint and individualized systemic therapy with its associated dramatic decrease in mortality has been a long one, hedged around by many carefully prepared clinical trials $[1,2,19,20]$. The current reservations against participating in clinical trials $[3,4]$ are therefore difficult to understand in view of the successes achieved by these treatments [5-7]. Quite possibly this reservation is due to concerns of patients and physicians that by taking part in the study they will be subject to the constraints of an experiment they do not fully understand, that information on first-line treatments might be deliberately withheld from them, and that the relationship between physician and patient could be undermined because of the requirements of the study.

A total of 251 centers were recruited and 3754 patients enrolled in the study over a period of 18 months up until the end of randomization in March 2007, making the SUCCESS-A trial one of the best recruited studies for this therapy in Germany [8]. The aim of this retrospective investigation was to find out from the centers that had participated in the study what impact participating in a prospective randomized phase III trial had on patient care within the centers over and beyond the study endpoints. All centers that participated in the study and enrolled patients were also asked about the impact of the study on established treatment strategies and whether the regular provision of information had improved their knowledge base. Did participation in the study lead to an improvement and intensification of patient care?

\section{Method}

$\nabla$

\section{SUCCESS-A study design}

Primary aim of the study was a comparison of disease-free survival after randomization of patients who received adjuvant treatment consisting of 3 cycles of fluorouracil, epirubicin and cyclophosphamide (FEC) followed by 3 cycles of docetaxel (D) with that of patients treated with 3 cycles of FEC chemotherapy followed by 3 cycles of gemcitabine and docetaxel (DG), as well as a comparison of disease-free survival after a second randomization of patients treated with zoledronate for 2 years or 5 years respectively ( $\bullet$ Fig. 1). Secondary criteria were defined as: overall survival after randomization; absence of distant metastasis; survival; toxicity; quality of life; skeletal morbidity and the incidence of secondary cancers. The predictive and prognostic value of minimal residual disease (MRD) in peripheral blood was determined for translational research [9].

Inclusion criteria were primary epithelial invasive breast cancer (pT1-4, pM0) and histological evidence of axillary lymph node metastasis ( $\mathrm{pN} 1-3)$. Alternatively, node-negative high-risk patients (N0/x) were included if they had pT2 tumors, were histologic grade 3 , aged $>35$ or had a negative hormone receptor status. A further criterion for inclusion in the study was $\mathrm{R} 0$ resection of the primary tumor not more than 6 weeks prior to randomization.

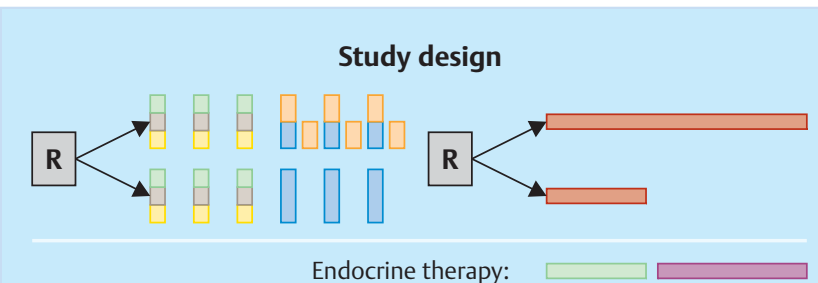

MRD monitoring in peripheral blood

Evidence of circulating tumor cells and tumor markers in peripheral blood prior to chemotherapy, after chemotherapy, 2 years after chemotherapy, and 5 years after chemotherapy.

5-fluorouracil $500 \mathrm{mg} / \mathrm{m}^{2}$, epirubicin $100 \mathrm{mg} / \mathrm{m}^{2}$, cyclophosphamide $500 \mathrm{mg} / \mathrm{m}^{2} \mathrm{q} 3 \mathrm{w}$

Docetaxel $100 \mathrm{mg} / \mathrm{m}^{2} \mathrm{q} 3 \mathrm{w}$

Docetaxel $75 \mathrm{mg} / \mathrm{m}^{2}$, gemcitabine $1000 \mathrm{mg} / \mathrm{m}^{2} \mathrm{~d} 1,8 \mathrm{q} 3 \mathrm{w}$

Zoledronate $4 \mathrm{mg} \times 2$ a vs. $5 \mathrm{a}$

$(\mathrm{q} 3 \mathrm{~m} \times 24 \mathrm{~m}$ vs. q3m $\times 24 \mathrm{~m}$ followed by $\mathrm{q} 6 \mathrm{~m} \times 36 \mathrm{~m})$

Tamoxifen $20 \mathrm{mg}$ qid p.o. $\times 2$ a (plus goserelin

$3,6 \mathrm{mg}$ depot $\times 2 \mathrm{a}$ in pre-menopausal women)

Anastrozole $1 \mathrm{mg}$ qid p.o. $\times 3$ a in post-menopausal patients (tamoxifen in pre-menopausal patients)

\section{Randomization A:}

AA: 5 -fluorouracil $500 \mathrm{mg} / \mathrm{m}^{2}$ and epirubicin $100 \mathrm{mg} / \mathrm{m}^{2}$ und cyclophosphamide $500 \mathrm{mg} / \mathrm{m}^{2}$ i.v. $\mathrm{q} 3 \mathrm{w} \times 3$ (all only administered on day 1 ) followed by docetaxel $75 \mathrm{mg} / \mathrm{m}^{2}$ (only on day 1 ) and gemcitabine $1000 \mathrm{mg} / \mathrm{m}^{2}$ i.v. (administered on days 1 and 8, $30 \mathrm{~min}$ infusion) $q 3 w \times 3$

AB: 5-fluorouracil $500 \mathrm{mg} / \mathrm{m}^{2}$ and epirubicin $100 \mathrm{mg} / \mathrm{m}^{2}$ and cyclophosphamide $500 \mathrm{mg} / \mathrm{m}^{2}$ i.v. q3w $\times 3$ followed by docetaxel $100 \mathrm{mg} / \mathrm{m}^{2}$ i.v. $q 3 w \times 3$ (all administered on day 1 )

Randomization B:

BA: Zoledronate $4 \mathrm{mg}$ i.v. q3m $\times 24 \mathrm{~m}$ followed by zoledronate $4 \mathrm{mg}$ i.v. $q 6 \mathrm{~m} \times 36 \mathrm{~m}$

BB: Zoledronate $4 \mathrm{mg}$ i.v. $\mathrm{q} 3 \mathrm{~m} \times 24 \mathrm{~m}$

Fig. 1 Treatment and randomization protocol of the SUCCESS-A trial.

Only physically resilient adult patients were included in the study; all patients gave their informed consent prior to enrollment in the trial.

All inclusion and exclusion criteria were in accordance with the guidelines for clinical oncologic trials, in particular the guidelines for the respective chemotherapeutic agents. Treatment, therapy and monitoring were in accordance with the statutory provisions determined by the ethics committees involved, the BfArM (German Federal Institute for Drugs and Medical Devices) and good clinical practice (GCP).

\section{Questionnaire}

After enrollment was completed, a questionnaire with 6 multiple choice questions was sent to all 251 SUCCESS-A centers participating in the study. The questionnaire investigated the following aspects ( $\odot$ Fig. 2 ): previous participation in clinical trials; previously used chemotherapy regimes for the same indication; changes in the intensity of care (excluding the additional time required for the study) due to participation in the trial; the increase in information relevant to treatment (e.g. information obtained from the study protocol, the coordinating center of the clinical study, the SUCCESS newsletter or study meetings); an assess- 
ment of the changes in medical treatment and care due to recruitment into the SUCCESS-A trial, as well as whether - after the experiences with the SUCCESS-A trial - the center would be prepared to take part in other clinical phase III trials in future.

\section{Statistical analysis}

Statistical analysis was done using PASWStats17.0.2; graphs and diagrams were created using Microsoft Office (Version 12.2.0) and Adobe Illustrator CS4 (Version 14.0.0). T-test was used for statistical analysis and $\mathrm{p}$-values of $<0.05$ were considered statistically significant.

Analysis of the responses was started half a year after the questionnaires were sent out. Completed questionnaires sent after this date were not included in the retrospective analysis.

\section{Results}

$\nabla$

\section{Course of the SUCCESS-A trial}

Between 1 September 2005 and 12 March 2007, 3754 patients were enrolled in the SUCCESS-A trial. Of the 271 registered study centers, 251 (93\%) study centers actively enrolled patients for the trial. A total of 158 patients were enrolled every month in the first 6 months of the trial, which increased to 236 patients per month after 12 months, and 246 patients per month at 18 months [8].

\section{Results of the survey}

In the first 3 months after the questionnaires were sent out, the response rate for all 251 centers was $21 \%$ (61 of 251). At the end of the predetermined response time of half a year, 86 study centers had completed and returned the questionnaire. Eight questionnaires had to be excluded from the analysis because of incomplete or non-standard answers.

A total of 94 study centers (38\%) responded to the questionnaire sent out by the study group. The centers participating in the SUCCESS-A trial were German university hospitals, oncology practices and hospitals. An evaluation of the centers who responded to the questionnaire showed no significant differences with regard to the size of the participating center (number of patients with primary breast cancer treated per year), the number of patients from the center enrolled in the study, and the German federal state where the hospital or medical practice was located. Nor was the response from centers that had enrolled high numbers of patients higher compared to that of centers that had only enrolled a single patient. It was notable that more questionnaires were returned from university hospitals and from physicians with their own practice than from other hospitals (40 vs. 39 vs. $35 \%$ ), although the differences were not statistically significant. For $40 \%$ of the participating study centers, it was the first time they had enrolled patients with this indication in a clinical trial. Prior to participation of the respective center in the SUCCESS-A trial, in $46 \%$ ( $n=36$ ) of centers patients with this indication were treated with anthracycline-based chemotherapy (FEC 100/120 or $4 \times \mathrm{A} / \mathrm{EC})$, patients in $50 \%(\mathrm{n}=39)$ of centers received taxanebased therapy (e.g. FEC-Doc or TAC), and patients in $3.8 \%(n=3)$ of centers received CMF chemotherapy or another chemotherapy not specified in the questionnaire.

$50 \%$ of centers reported a higher intensity of medical care (excluding the additional time required to record the results of the study) after participating in the SUCCESS-A trial. The other $50 \%$ reported that the intensity of care had remained the same. The

\section{Questionnaire}

Question 1: Prior to participating in the SUCCESS-A trial did you enroll similar patients (primary breast cancer, NO with risk factors or $\mathrm{N} 1-3$ ) in another therapy optimization trial (not a non-interventional observational study)?

$\square$ Yes

$\square$ No

Question 2: What was the chemotherapy regime given to similar patients prior to enrollment in the SUCCESS-A trial?

CMF or other

Anthracycline-based (FEC 100/120 oder $4 \times$ A/EC)

Taxane-based (e.g. FEC-Doc or TAC)

Question 3: Did participation in the SUCCESS-A trial affect the intensity of the medical care given to patients (excluding the time required for documentation)?
$\square$ Decreased
$\square$ Remained the same
$\square$ Increased

Question 4: Did participation in the SUCCESS-A trial provide you with additional information which improved the medical care given to patients (e.g. information from the study protocol, the study group, the SUCCESS-A newsletter or study meetings)?
$\square$ Not applicable
$\square$ Not very applicable
$\square$ Moderately applicable
$\square$ Highly applicable

Question 5: In your opinion, did the overall quality of medical care (taking the various factors such as oncologic safety, side effects, intensity of care into account) of patients change after enrollment in the SUCCESS-A trial?

$\square$ Worsened
$\square$ Remained the same
$\square$ Improved

Question 6: Based on your experience with the SUCCESS-A trial would you participate in a clinical phase III trial again in future?

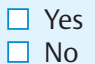

Fig. 2 Questionnaire on the satisfaction of the centers.

intensity of care did not decrease in any of the participating centers. $47 \%(n=37)$ of centers reported a big increase in treatmentrelevant information through their participation in the trial. A further $46 \%(n=36)$ of centers reported an increase in treatment-relevant information and only 5 centers reported no or only a limited increase in information.

According to their own statements, after taking various factors such as oncologic safety, side-effects and intensity of care into account, $47 \%$ of participating centers increased the overall quality of their medical care. In $53 \%$ of centers, the quality of care remained the same, and none of the survey centers reported a decline in the overall quality of care.

In response to the question whether they would be prepared to take part in another phase III trial after their experience with the SUCCESS-A trial, $100 \%(n=78)$ of the survey centers answered in the affirmative ( $\bullet$ Fig. 3 ). 


\section{Discussion}

$\nabla$

The reduction of breast cancer mortality in Western countries is one the great success stories of scientific medicine in the past two decades [1]. Thus, further investigation of breast cancer patients is useful. A frequently discussed and still unresolved question is whether it is permissible to make use of patients with disease for scientific purposes and for the benefit of future patients. Does participation in a study deflect physicians from their intrinsic mission, namely the care of individual patients? Or does inclusion and involvement in a larger network and a prescribed therapy regime also improve the care given to patients?

This was the question we aimed to answer in our survey with the help of the centers participating in the SUCCESS-A trial. With a rate of $31 \%$ (completed and valid questionnaires) of questionnaires returned from 251 centers, the sample was in accordance with the response rate reported for other, similar, systematic investigations [10].

For $40 \%$ of centers participating in the SUCCESS-A trial, it was the first time they had ever enrolled breast cancer patients in a clinical trial. The aim of our phase III trial is to develop optimized tumor therapies for future use and to confirm the benefit of these therapies using sound data obtained from a clinical trial. The wider the range of data obtained, the more efficiently patients can be enrolled in a study, and the more experience a recruiting center has with clinical trials, the quicker it is possible to obtain good quality data [10].

In the ADEBAR trial (recruitment between 2001 and 2004) which was supervised by the same study group, for $63 \%$ of all participating centers it was the first time they had taken part in a clinical trial [11].

We also investigated the therapeutic benefit for the patients enrolled in the study. Although prior to their enrollment into the SUCCESS-A trial the majority of patients were already receiving therapy in accordance with current standards, the clinical trial offered patients access to an innovative treatment concept tailored to patients with these indications, and consisted of the administration of zoledronate $\left(4 \mathrm{mg} / \mathrm{m}^{2}\right)$ for 2 or 5 years and anti-endocrine therapy with tamoxifen and aromatase inhibitors [12]. The choice of chemotherapeutic agents was similarly innovative: both arms of the SUCCESS-A trial for which patients were enrolled from September 2005, were taxane-based. Half of all participating centers had previously followed non taxane-based regimes when treating patients with these indications. The St. Gallen Consensus of January 2005 had already suggested that taxanes should be administered to high-risk patients, so that a study design without taxane in both arms of the study would no longer have complied with current standards for this high-risk collective [13]. The recommendation to additionally administer taxanes to high-risk patients was subsequently included in the St. Gallen Consensus of 2007 [14].

The vast majority of centers reported that they had benefited from the extensive treatment-relevant information of the study communications (e.g. study protocol, newsletter and meetings). Based on this self-evaluation, the increase in knowledge obtained through participating in the study was not limited to the study endpoints but also had a positive impact on the medical care given to patients during the trial [15]. This assumption is supported by the increase in the intensity of care reported by the individual centers during the trial. The centers associated the close monitoring and more intensive follow-up with the increased time spent on documentation, while patients associated it with greater care

\begin{tabular}{|c|c|c|}
\hline \multicolumn{3}{|c|}{ Previous participation in clinical trials } \\
\hline Yes & & $60.3 \%(n=47)$ \\
\hline No & & $39.7 \%(n=31)$ \\
\hline \multicolumn{3}{|c|}{ Previous therapy regimes } \\
\hline CMF or other & & $3.8 \%(n=3)$ \\
\hline Anthracycline-based & $\mid \|$ & $46.2 \%(n=36)$ \\
\hline Taxane-based & & $50 \%(n=39)$ \\
\hline \multicolumn{3}{|c|}{ Intensity of care through participation in the trial } \\
\hline \multicolumn{3}{|l|}{ Decreased } \\
\hline Remained the same | & |||||||| & $50 \%(n=39)$ \\
\hline Increased & & $50 \%(n=39)$ \\
\hline \multicolumn{3}{|c|}{ Increase in treatment-relevant information } \\
\hline None & & $3.8 \%(n=3)$ \\
\hline Somewhat & $\|$ & $2.6 \%(n=2)$ \\
\hline Moderate & & $46.2 \%(n=36)$ \\
\hline Large & |||||| & $47.4 \%(n=37)$ \\
\hline
\end{tabular}

Overall quality of medical care

Decreased

Remained the same

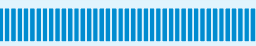

$52.6 \%(n=41)$

Improved

||||||||||||||||||||||||||||||||||||||

$47.4 \%(n=37)$

Willing to participate in a clinical trial again in future

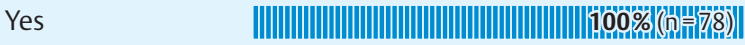

No

| = Study center

Fig. 3 Results of the survey.

from their attending physician. A possible argument against enrollment in a study is that the increased time spent on documentation could deflect attention from patient care. The fact that a majority of centers had already previously taken part in clinical trials has surely resulted in documentation becoming more routine; thus the reported increase in the intensity of care is all the more remarkable. It is also reflected in the increase in overall quality of medical care reported by $50 \%$ of centers. It is also astonishing in this context that not one of the centers reported a decrease in quality due to participation in the trial.

Thus, the research into better therapies for future patients was not done at the expense of decreasing the medical care of current patients. Quite the contrary.

Sound data showing a direct benefit of study enrollment for patients are rare. Hébert-Croteau et al. analyzed total survival in 1727 patients with breast cancer who were either enrolled in a clinical trial or were treated in accordance with clinical guidelines. Multivariate analysis showed an independent total survival benefit, despite adjusting for age, co-morbidities, grading, hormone receptor status, tumor stage and local therapies [16].

Although the basic superiority of taxane and anthracycline-based chemotherapy compared to anthracycline chemotherapy alone posited in our study collective will continue to be a subject of discussion, it should be pointed out that patients in $4 \%$ of the study 
centers were being treated with less effective chemotherapies and thus were receiving treatment which did not comply with current standards. This was improved through the participation in the study.

With our study we were able to show that patient care improves, the knowledge base of participating centers expands and the overall quality of care is improved by participation in a clinical trial. All study centers reported that they were prepared to enroll patients in clinical trials again in the future.

This is a result that fills us with pride and encourages us to continue with our combined efforts to develop optimal therapies for patients with breast cancer.

\section{Acknowledgements}

$\nabla$

The authors would like to thank all patients who participated in the SUCCESS-A- trial, their families, the staff of the central study registry in Munich, and the study centers listed below for their commitment and dedication:

Klinikum der Universität München Innenstadt, München | Praxis Dr. Ruhmland, Berlin | Universitätsklinikum des Saarlandes, Homburg/Saar | Gemeinschaftspraxis Siehl/Söling, Kassel | Gemeinschaftspraxis Dr. med. Weniger/Dr. med. Bittrich, Erfurt | Praxis Dr. Enser-Weis, Bochum | Achenbach Krankenhaus, Königs Wusterhausen | Gemeinschaftspraxis Dr. Bojko, Dr. Abenhardt, Dr. Bosse, München | Carl-von-Basedow-Klinikum, Merseburg | DRK - Kliniken Köpenick, Akademisches Lehrkrankenhaus der Charité, Berlin | Pius Hospital, Oldenburg | Leopoldina Krankenhaus Schweinfurt gGmbH, Schweinfurt | Kreiskrankenhaus Emmendingen, Emmendingen | Hämatologische Schwerpunktpraxis Stade, Stade | Praxis Dr. Bückner, Bochum | Gemeinschaftspraxis Dr. Forstbauer/Dr. Ziske, Troisdorf | Enzkreisklinikum, Mühlacker | Paracelsus-Krankenhaus Ruit, Ostfildern-Ruit | Praxis Dr. Heinrich, Fürstenwalde | Praxis Prof. Kleeberg/Dr. Engel, Hamburg | Klinikum Kirchheim-Nürtingen, Nürtingen | Praxis Dr. Fett, Wuppertal | Städtisches Klinikum Brandenburg, Brandenburg | Praxis Dr. Nawka, Berlin | Bethesda Krankenhaus Wuppertal gGmbH, Wuppertal | Kreiskrankenhaus Gifhorn, Gifhorn | Marienhospital Gelsenkirchen, Gelsenkirchen | Praxis Dr. Strotkötter, Wuppertal | Praxis Dr. Schulze hämato-onkologische Schwerpunktpraxis, Zittau | Städtisches Klinikum St. Georg, Leipzig | Städtisches Klinikum Rosenheim, Rosenheim | St. ElisabethKrankenhaus GmbH, Köln | Klinikum der Albert-Ludwig-Universität Freiburg, Freiburg | Stadtklinik Baden-Baden, Baden-Baden | Ev. Amalie Sieveking Krankenhaus e.V., Hamburg | Klinikum Pforzheim GmbH, Pforzheim | Klinik Sankt Marienstift, Magdeburg | Friederikenstift Hannover, Hannover | Praxis Dr. Gehbauer, Ingolstadt | Praxis Dr.Kröning, Magdeburg | Südharzkrankenhaus, Nordhausen | Charité Campus Virchow-Klinikum Universitätsmedizin Berlin, Berlin | Klinikum Obergöltzsch Rodewisch, Rodewisch | Kreiskrankenhaus Eggenfelden, Eggenfelden | Praxis Zimber/Brendel/Hoesl/Maintz, Nürnberg | Kreiskliniken Reutlingen $\mathrm{GmbH}$, Reutlingen | Klinikum Kempten Oberallgäu gGmbH, Kempten | ASKLEPIOS Klinik Barmbek, Hamburg | St. Marienhospital Vechta, Vechta | Kliniken Ludwigsburg-Bietigheim gGmbH, Bietigheim | Brustzentrum Oberschwaben, Weingarten | Katholisches Klinikum Mainz St. Vincenz- u. Elisabeth-Hospital, Mainz | Ev. Krankenhaus, Zweibrücken | Universitätsfrauenklinik, Tübingen | Universitätsklinik Würzburg, Würzburg | Kreiskrankenhaus Rottweil, Rottweil | Gemeinschaftspraxis Dr. Heine/Dr. Haessner, Wolfsburg | Henriettenstiftung Krankenhaus, Hanno- ver | Praxis Dr. Papke, Neustadt (Sachsen) | Franziskus-Hospital GmbH, Bielefeld | Städt. Kliniken Esslingen, Esslingen | Gemeinschaftspraxis Dr. Hornberger/Dr. Tanzer, Bad Reichenhall | Klinikum Frankfurt an der Oder, Frankfurt/Oder | St. Vincenz Krankenhaus, Limburg | Praxis Dr. Deertz, Essen | Kreiskrankenhaus Mittleres Erzgebirge gGmbH, Zschopau | Praxis Prof. Tesch, Frankfurt | DRK Krankenhaus, Sondershausen | Klinikum Hoyerswerda gGmbH, Hoyerswerda | Klinikum Chemnitz gGmbH, Chemnitz | DRK Krankenhäuser Sömmerda und Bad Frankenhausen, Sömmerda | Praxis/Klinik Drs. Garbe/Wienecke/Mattner/Windscheid, Hamburg | Klinikum Dorothea Christiane Erxleben Quedlinburg gGmbH, Quedlinburg | Thüringen-Klinik Georgius Agricola gGmbH, Saalfeld | Hochwald Krankenhaus, Bad Nauheim | SRH Wald-Klinikum Gera gGmbH, Gera | Praxis Dr. Stauch, Kronach | Caritas-Krankenhaus St. Josef, Regensburg | Klinikum Coburg, Coburg | Klinikum St. Marien Lehrkrankenhaus der Universität Erlangen-Nürnberg, Amberg | Praxis Dr. Gampe, Bad Windsheim, Klinikum Meiningen GmbH, Meiningen | DRK Krankenhaus Luckenwalde, Luckenwalde | Sana-Klinikum Hof, Hof | Städtisches Krankenhaus, Wertheim | Kreiskrankenhaus Stadthagen, Stadthagen | Haematolgisch-onkologische Schwerpunktpraxis, Cottbus | Albertinen-Krankenhaus, Hamburg | Klinikum Marienhospital Ruhr-Universität Bochum, Herne | Ev. Krankenhaus Mülheim, Mülheim/Ruhr | Klinikum Landkreis Tuttlingen, Tuttlingen | Gemeinschaftspraxis Dr. med. Hahn/Dr. med Müller, Ansbach | Johanniter Krankenhaus, Bonn | Krankenhaus Forchheim, Forchheim | Städt. Kliniken Kassel, Kassel | Gemeinschaftspraxis der Frauenärzte, Roth | Paracelsus-Klinik Henstedt-Ulzburg, Henstedt-Ulzburg | Praxis Dr. Glados, Coesfeld | HELIOS-BZ Nordsachsen, Schkeuditz | Asklepios Klinik Bad Oldesloe, Bad Oldesloe | Kreiskrankenhaus Leonberg, Leonberg | Praxis Dr. Baerens, Ilsede | St. Antonius-Hospital, Eschweiler | Gemeinschaftspraxis Dr. Göhler/Dipl. med. Dörfel, Dresden | Klinikum Garmisch-Partenkirchen $\mathrm{GmbH}$, Garmisch-Partenkirchen | Gemeinschaftspraxis Muhr am See, Muhr am See | Klinikum der Stadt Ludwigshafen am Rhein gGmbH, Ludwigshafen | Westfälische Wilhelms Universitätsklinik Münster | Kreiskrankenhaus Aschersleben-Staßfurt gGmbH, Aschersleben | Kreiskrankenhaus Hameln, Hameln | Tagesklinik Altonaer Straße, Hamburg | Asklepios Krankenhäuser GmbH Weißenfels, Weißenfels | St. Salvator-Krankenhaus Halberstadt gGmbH, Halberstadt | Klinikum Ingolstadt, Ingolstadt | Luisenkrankenhaus GmbH \& Co. KG, Düsseldorf | Zentralklinikum gGmbH Südthüringen, Akademisches Lehrkrankenhaus der FSU Jena, Suhl | DRK Krankenhaus Saarlouis, Saarlouis | Ostalb-Klinikum, Aalen | Klinikum Landsberg, Landsberg | REMS-MURR-KLINIKEN, Waiblingen | HUMAINE Vogtland Klinikum Plauen GmbH, Plauen | Katharinen-Hospital gGmbH, Unna | Klinikum Saarbrücken gGmbH, Saarbrücken | Praxisklinik Dr. Kittel/Dr. Klare, Berlin | Klinikum Bremerhaven Reinkenheide, Bremerhaven | Gemeinschaftspraxis Dr. Dietz/Witte-Dietz, Salzgitter-Lebenstedt | Gemeinschaftspraxis Dr. R. Lorenz/N. Hecker, Braunschweig | Ev. Waldkrankenhaus Spandau, Berlin | Praxis Dr. med. Dagmar Guth, Plauen | Gemeinschaftspraxis Dr. Kronawitter/Dr. Jung, Traunstein | Praxis Dr. Wilke, Fürth | Klinikum Fulda gAG, Fulda | Klinikum der Friedrich-Schiller-Universität Jena, Jena | Gemeinschaftspraxis Dr. Schönleber \& Dr. Graffunder, Berlin | Gemeinschaftspraxis Vaupel/Wolter/Robertz-Vaupel/Eßer/Schäfer-Haas, Bonn | St. Vincentius-Kliniken g AG, Karlsruhe | Klinikum Großhadern, München | Städtisches Klinikum Lüneburg, Lüneburg | Kreiskrankenhaus Gummersbach GmbH, Gummersbach | Klinikum Hannover Nordstadt, Hannover | Sächsische Schweiz Klinik Sebnitz, Sebnitz | Praxis Dr. Kalischefski, Waldmünchen | Klini- 
kum Ludwigsburg, Ludwigsburg | Klinikum Neumarkt, Neumarkt | St. Johannis Krankenhaus gGmbH, Landstuhl | Praxis Dr. Elbe, Ettlingen | Diakonissenkrankenhaus Flensburg, Flensburg | Krankenhaus St. Elisabeth und St. Barbara, Halle | Katholisches Krankenhaus Leipzig St. Elisabeth, Leipzig | Kreiskrankenhaus Bitterfeld/Wolfen, Bitterfeld | Klinik am Eichert, Göppingen | Zentralklinikum Augsburg, Augsburg | Praxis Dr. Uhlig, Naunhof | Universitätsfrauenklinik Erlangen, Erlangen | Stadtkrankenhaus Hanau, Hanau | Klinikum Herford, Herford | Praxis Dr. Dengler/ Dr. Kröber, Regensburg | Klinikum Schwäbisch Gmünd, Mutlangen | Stadtkrankenhaus Worms gGmbh, Worms Krankenhaus Böblingen, Böblingen | Hanse-Klinikum Strahlsund GmbH, Stralsund | Harz-Klinikum Wernigerode-Blankenburg GmbH, Wernigerode | Praxis Dr. Schilling, Berlin | Kliniken des Landkreises Berchtesgadener Land GmbH, Bad Reichenhall | Marienkrankenhaus St. Wendel, St. Wendel | Amper Kliniken AG, Dachau | Robert-Bosch-Krankenhaus, Stuttgart | Charité Campus Benjamin Franklin, Berlin | Asklepios Klinik Lich GmbH, Lich | Klinikum Memmingen, Memmingen | Praxis Dr. Hindenburg, Berlin Städtisches Klinikum Magdeburg, Krankenhaus Altstadt, Magdeburg | Kreiskrankenhaus Torgau, Torgau | Caritas Klinik St. Theresia, Saarbrücken | Friedrich-Ebert-Krankenhaus Neumünster, Neumünster | Praxis Dr. Blümel, Magdeburg | St. Franziskus-Hospital, Ahlen | Westküstenklinikum, Heide | Süd Eifel-Kliniken Bitburg, Bitburg | St. Anna Krankenhaus, Sulzbach-Rosenberg | Klinikum Itzehoe, Itzehoe | Klinikum Bayreuth, Bayreuth | Praxis Dr. Mölle, Dresden | Kreiskrankenhaus Rendsburg, Rendsburg | Universitätsfrauenklinik, Heidelberg | Georg-August-Universität Göttingen, Göttingen | Klinikum Landshut gGmbH, Landshut | Universitätsklinik Mainz, Mainz | Fürst-Stirum-Klinik, Bruchsal | Städt. Klinikum Karlsruhe, Akademisches Lehrkrankenhaus der Universität Freiburg, Karlsruhe | Universitätsklinikum Schleswig-Holstein Campus Kiel, Kiel | Universitätsklinik Carl Gustav Carus der TU Dresden, Dresden | Praxis Dr. Doering, Bremen | Universitätsklinikum Hamburg-Eppendorf, Hamburg | Kreiskrankenhaus Belzig GmbH, Belzig | Praxis Dr. Vehling-Kaiser, Landshut | Helios Klinikum Berlin - Klinikum Buch, Berlin | Helfenstein Klinik, Geislingen an der Steige | Diakonissenkrankenhaus Dessau gGmbH, Dessau | Klinikum der Stadt Wolfsburg, Wolfsburg | Ernst-Moritz-Arndt-Universität, Greifswald | St. Barbara-Klinik Hamm Heessen GmbH, Hamm | Krankenhaus Siloah, Pforzheim | Kliniken Landkreis Biberach, Biberach | Praxis Dr. Laube Suhl | Praxis Dr. Busch, Mühlhausen | Hämatologisch-onkologische Gemeinschaftspraxis, Aschaffenburg | Praxis Dr. Müller, Leer | Praxis Dr. Seipelt, Bad Soden | Praxis Dr. Massinger-Biebl, Waldkirchen | Evang. Diakonie Krankenhaus Bremen, Städtisches Krankenhaus Martha-Maria Halle-Dölau gGmbH, Halle | Gemeinschaftspraxis Dr. H. Wolf \& A. Freidt, Dresden | Universitätsklinikum Schleswig-Holstein, Campus Lübeck, Lübeck | Klinikum am Gesundbrunnen, Heilbronn | Evangelische Kliniken Gelsenkirchen GmbH, Gelsenkirchen | Schwarzwald-Baar Klinikum VillingenSchwenningen GmbH, Villingen-Schwenningen | Landkreis Mittweida Krankenhaus gGmbH, Mittweida | Klinikum Lippe-Lemgo GmbH, Lemgo | Diakoniekrankenhaus Schwäbisch-Hall, Schwäbisch-Hall | Gemeinschaftspraxis Ardeystraße, Witten | Klinikum Nürnberg/Nord, Nürnberg | Klinikum Fichtelgebirge, Marktredwitz | Internist. Gemeinschaftspraxis Strauß/Rendenbach/Laubenstein, Trier | Medizinische Hochschule Hannover, Hannover | St. Josef Krankenhaus GmbH Moers, Moers | Gemeinschaftspraxis Dres N. Kalhori, A. Nusch, Velbert | Praxis Dr. Reles, Berlin | Gemeinschaftspraxis Leitsmann/Lenk, Zwickau | MAIN-KINZIG-KLINIKEN gGmbH, Krankenhaus Gelnhausen Akademisches Lehr- krankenhaus, Gelnhausen | Diakoniekrankenhaus, Rotenburg (Wümme) | KreisKH Delitzsch GmbH, Eilenburg | Gemeinschaftspraxis Prof. Salat/Dr. Stötzer, München | Gemeinschaftspraxis Bohnsteen/Hendrich, Dessau | Kreiskrankenhaus, Sigmaringen | Gemeinschaftspraxis Dr. Kappus/Dr. Schneider-Kappus, Ulm | Klinikum Konstanz, Konstanz | Kreiskrankenhaus Ebersberg, Ebersberg | Universitätsklinikum Ulm, Ulm | Marienhospital Brühl, Brühl | Gemeinschaftspraxis Dr. Pause/Dr. Thiel/Dr. Neuhofer, Freising | Klinikum Weiden i.d. Oberpfalz, Weiden | Kreiskrankenhaus Schorndorf, Schorndorf | Klinikum Südstadt, Rostock | Praxis Dr. Schlag, Würzburg | Praxis Dr. med. Klaus Apel, Erfurt | Gemeinschaftspraxis Dr. med. Bernhard Schleicher/Peter Schleicher, Schwandorf | Praxis Dr. Weiß, Weiden | Evangelisches Krankenhaus, Wesel | Krankenanstalten Mutterhaus der Borromäerinnen, Trier | Universitätsklinikum Gießen und Marburg GmbH, Marburg

\section{Conflict of Interest}

$\nabla$

None.

\section{Affiliations}

1 Klinik und Poliklinik für Frauenheilkunde und Geburtshilfe, Klinikum der Ludwig-Maximilians-Universität, München

2 Frauenklinik, Klinikum der Heinrich-Heine-Universität Düsseldorf, Düsseldorf

3 Frauenklinik, Klinikum Traunstein, Traunstein

${ }^{4}$ Brustzentrum der Universität, Klinikum der Ludwig-Maximilians-Universität, München

5 Frauenklinik, Klinikum rechts der Isar der TU München, München

${ }^{6}$ Frauenklinik, Universitätsklinikum, Erlangen

7 Frauenklinik, Klinikum der Universität UIm, Ulm

\section{References}

1 Peto $R$, Boreham J, Clarke $M$ et al. UK and USA breast cancer deaths down 25\% in year 2000 at ages 20-69 years. Lancet 2000; 355: 1822

2 Melcher C, Scholz C, Jäger B et al. Breast cancer: state of the art and new findings. Geburtsh Frauenheilk 2012; 72: 215-224

3 Grand MM, O'Brien PC. Obstacles to participation in randomised cancer clinical trials: a systematic review of the literature. J Med Imaging Radiat Oncol 2012; 56: 31-39

4 Lamunu D, Chapman KN, Nsubuga P et al. Reasons for non-participation in an international multicenter trial of a new drug for tuberculosis treatment. Int J Tuberc Lung Dis 2012; 16: 480-485

5 Ezeugwu CO, Laird A, Mullins CD et al. Lessons learned from community-based minority health care serving system participation in an $\mathrm{NIH}$ clinical trial. J Natl Med Assoc 2011; 103: 839-844

6 Goyal J, Nuhn P, Huang P et al. The effect of clinical trial participation versus non-participation on overall survival in men receiving first-line docetaxel-containing chemotherapy for metastatic castration-resistant prostate cancer. BJU Int 2012; DOI: 10.1111/j.1464-410X.2012.11286.x

7 Kümmel S, Kolberg HC, Lüftner D et al. Mammakarzinom 2011 - Neue Aspekte. Geburtsh Frauenheilk 2011; 71: 939-953

8 Janni W, Salmem J. Mammakarzinom: Was bringt die SUCCESS-Studie Neues? Geburtsh Frauenheilk 2010; 70: 330-331

9 Hartkopf $A D$, Banys $M$, Krawczyk $N$ et al. Circulating tumor cells in early-stage breast cancer. Geburtsh Frauenheilk 2011; 71: 1067-1072

10 Lawton J, Jenkins N, Darbyshire J et al. Understanding the outcomes of multi-centre clinical trials: a qualitative study of health professional experiences and views. Soc Sci Med 2012; 74: 574-581

11 Janni W, Kiechle M, Sommer H et al. Study participation improves treatment strategies and individual patient care in participating centers. Anticancer Res 2006; 26: 3661-3667

12 Rack B, Juckstock J, Genss EM et al. Effect of zoledronate on persisting isolated tumour cells in patients with early breast cancer. Anticancer Res 2010; 30: 1807-1813

13 Goldhirsch A, Glick J, Gelber R et al. Meeting highlights: international expert consensus on the primary therapy of early breast cancer 2005. Ann Oncol 2005; 16: 1569-1583 
14 Goldhirsch A, Wood W, Gelber R et al. Progress and promise: highlights of the international expert consensus on the primary therapy of early breast cancer 2007. Ann Oncol 2007; 18: 113-144

15 Schindowski D. Optimierte Studiendurchführung zur Steigerung der Anzahl von Studienpatientinnen an Brustzentren. Senologie - Zeitschrift für Mammadiagnostik und -therapie 2009; 6: A101

16 Hebert-Croteau N, Brisson J, Lemaire J et al. The benefit of participating to clinical research. Breast Cancer Res Treat 2005; 91: 279-281

17 Lüftner D, Lux MP, Maass $N$ et al. Advances in breast cancer - looking back over the year. Geburtsh Frauenheilk 2012; 72: 1117-1129
18 Schmidt M, Fasching PA, Beckmann MW et al. Biomarkers in breast cancer - an update. Geburtsh Frauenheilk 2012; 72: 819-832

19 Dieterich $M$, Dieterich $H$, Moch $H$ et al. Re-excision rates and local recurrence in breast cancer patients undergoing breast conserving therapy. Geburtsh Frauenheilk 2012; 72: 1018-1023

20 Rhiem K, Pfeifer K, Schmutzler RK et al. Risk-reducing surgery in women at risk for familial breast or ovarian cancer. Geburtsh Frauenheilk 2012; 72: 833-839

Deutschsprachige Zusatzinformationen online abrufbar unter: www.thieme-connect.de/ejournals/toc/gebfra. 